\title{
Retranslating the Brazilian Imperial Project: O Novo Mundo's Depictions of the 1876 Centennial Exhibition
}

\author{
KRISTA BRUNE \\ Pennsylvania State University
}

\begin{abstract}
As the first world's fair held in the Americas, the 1876 Centennial Exhibition in Philadelphia allowed the hemisphere's nations to stake disparate claims to modernity through unequal displays of natural resources, new technologies, and art. Existing scholarship on the Centennial Exhibition and its importance for Brazil touches only briefly on how representations of Brazil at the fair were communicated to the Brazilian public. This article claims that Brazil's participation at the fair created translations of the nation for a foreign public that were retranslated for Brazilian readers through O Novo Mundo, a periodical published in New York from 1870 to 1879. By reading O Novo Mundo alongside archival documentation and histories of the Centennial Exhibition, I contend that the periodical recognized Brazil's desire for modernity, critiqued how Brazilian officials wanted the nation to be seen, and questioned how models of progress from the United States would unfold in Brazil.
\end{abstract}

Keywords: Nineteenth-century Brazil, modernity, world's fairs, translation, hemispheric Americas

As the first world's fair held in the Americas, the 1876 Centennial Exhibition in Philadelphia allowed the hemisphere's nations, most notably the United States and Brazil, to stake disparate claims to modernity through unequal displays of 
natural resources, technologies, and creative expressions. O Novo Mundo, a Portuguese-language periodical edited by José Carlos Rodrigues (1844-1922) and published in New York for a Brazilian readership from 1870 to 1879, depicted Brazil's participation in the Philadelphia exhibition and other world's fairs. ${ }^{1}$ The journal showcased the interactions between leaders of the United States and Brazil at the inauguration of the Centennial Exhibition on May 10, 1876. President Ulysses S. Grant and Emperor Dom Pedro II toured the grounds, accompanied by four thousand invited guests. They examined national displays as they made their way to the industrial centerpiece of the exhibition, the Corliss engine. Turning the wheels on the enormous machine, the two heads of state started the generator that would power the other displays in the machinery hall. ${ }^{2}$ With this symbolic act, Grant and Pedro II affirmed their belief and investment in Eurocentric visions of progress as a scientific, teleological ideal that could provide solutions to the difficulties ailing their nations.

O Novo Mundo suggested that embracing natural resources and promoting new technologies could allow these leaders to differentiate their countries from European nations and, in the process, achieve greater global prominence. This "illustrated magazine of the progress of the era" circulated among readers in Brazil and served as a translator establishing hemispheric links with articles and images depicting new technologies, political developments, educational practices, and cultural expressions from mainly the United States. Proponents of a hemispheric perspective, including Rodrigues, did not fully foresee the imperial implications of a close relationship with the United States. Scientific writings and related articles in O Novo Mundo employed a language of shared discovery and continued exchange in the name of "progress" that minimized the danger of exploring Brazil's land and extracting its natural resources. Rodrigues and his contemporaries did not envision cycles of exploitation as epitomized by the

\footnotetext{
${ }^{1}$ See Boehrer for a historical overview of Rodrigues and O Novo Mundo. Previous theses by Rinaldi Asciutti and Campos focus on the periodical's literary connections, such as the journalistic contributions of the poet Sousândrade and the 1873 publication of Machado de Assis's famous essay on the instinct of nationality in Brazilian literature.

${ }^{2}$ See Rydell 9-16 for an overview of the exhibition's opening. To see this exchange from a Brazilian viewpoint, see Schwarcz, “Os trópicos como espetáculo” 208-10; chapter 15 of her The Emperor's Beard; and Barman 275-80.
} 
rubber boom that would begin a few years later. ${ }^{3}$ For these Brazilian elites writing from New York, it seemed possible to establish a mutually beneficial relationship between Brazil and the United States, as exemplified by the Centennial Exhibition and its documentation in O Novo Mundo.

While the United States would soon emerge as a global force of industrial capitalism, Brazil would remain on the political and economic margins as a nation of primitive accumulation whose wealth depended on agriculture and resource extraction. Touring the Centennial Exhibition together, however, allowed the president and the emperor to envision the possibilities for their nations during difficult periods of transition. As leaders in the Americas, they faced similar challenges of governing diverse peoples across an expansive territory, grappling with legacies and burdens of colonialism and slavery, and establishing a distinctive and unified national identity. The two countries were also worlds apart, with the United States a democracy recovering from a devastating Civil War and the failures of Reconstruction and Brazil a tropical monarchy holding onto the vestiges of slavery. ${ }^{4}$ The encounter between the president and the emperor on the exhibition's opening day provides an entrance into exploring the shared desires for and distinct claims to modernity held by the United States and Brazil as nations of the Americas on the precipice of change. In upcoming decades, reforms of political systems and labor structures in both countries would facilitate their embrace of industrial capitalism to varying degrees as the hemisphere increasingly became a center of capital. The layout and events of the Philadelphia exhibition suggested this shift in geopolitical and economic power given the prominence of the United States, as the host nation, and Brazil, with its elaborate pavilions. The exhibition allowed each country to showcase their defining features as they translated curated visions of national identity and economic potential for a foreign public. Displays of raw materials, agricultural goods, technological innovations, and artworks allowed people to figuratively travel to distant lands without leaving the exhibition hall.

\footnotetext{
${ }^{3}$ See Beckman for more on the “export age,” a period of extraction ranging from 1875 to 1925 that corresponds with attempts, examined by Hardman, to implement global, capitalist modernity in the Brazilian jungle.

${ }^{4}$ Schwarcz's $O$ espetáculo das raças analyzes race, social practices, and beliefs in nineteenthcentury Brazil. See Costa and Seigel for historical comparisons of Brazil and the United States.
} 
Scholars of world's fairs, including Robert Rydell, Werner Plum, and Bruno Giberti, have examined the significance of the Philadelphia exhibition for the intersection of nationalism, modernity, and industrial capitalism in terms of public consumption, architectural space, and visual displays. Studies by Francisco Foot Hardman, Maria Inez Turazzi, and Lilia Moritz Schwarcz have noted the importance of universal exhibitions for the construction of Brazil as a "civilized" nation, in spite of its tropical geography. Existing scholarship touches only briefly, if at all, on how these representations of Brazil abroad were communicated to a public back at home. While displays at the Philadelphia fair translated an essential vision of Brazil for a foreign public, O Novo Mundo retranslated these images and ideas of the nation for a Brazilian readership, as I examine in this article. By speaking from a position in-between Brazil and the United States, the periodical, I contend, recognized Brazil's desire for modernity, critiqued how Brazilian officials planned to represent the nation abroad, and questioned how models of progress would unfold in Brazil.

\section{World's Fairs and the Spectacle of Modernity}

During the second half of the nineteenth century, international exhibitions emerged as an increasingly important venue for nations to showcase natural resources, new technologies, and culture. The exhibitions' physical size and public reach expanded over the course of the century to become popular celebrations of progress, industry, and technology. ${ }^{5}$ Universal exhibitions, as Plum accurately claims, served as "the popular self-portraits of the resourceful, creative industrial bourgeoisie” (6). Rydell similarly notes that the "world's fairs performed a hegemonic function precisely because they propagated the ideas and values of the country's political, financial, corporate, and intellectual leaders and offered these ideas as the proper interpretations of social and political reality" (3). These elite visions of the nation reached a broader public through universal exhibition displays, which served as the nineteenth-century equivalent to contemporary, televised global mega-events (Plum 64). As the "first truly mass-

\footnotetext{
${ }^{5}$ According to Plum, the 1851 London exhibition covered 8.4 hectares with 13,937 exhibitors and $6,039,195$ visitors. The Philadelphia fair covered 30.3 hectares with 60,000 exhibitors and 10,165,000 visitors. The 1900 Parisian fair covered 46 hectares with 83,000 exhibitors and $50,800,801$ visitors (63)
} 
mediatic form” (Andermann 333), exhibitions generated what Jens Andermann terms as "new forms of display and spectatorship [that] re-organized local systems of value” within the interconnected realm of global capital (334). With temporary displays of national wealth, fairs exemplified what Hardman describes as an "era of spectacle" fueled by bourgeois embraces of Eurocentric views of progress (63). Underscoring the spectacle of the fairs, Schwarcz claims that "era como se fosse preciso teatralizar a realidade e construir cenários” (“Os trópicos como espetáculo” 200). Rather than mimic the existing world, the exhibitions invented architectural styles and built temporary structures.

They showcased nations' prized resources and industrial goods before being dismantled, exemplifying the material consumption and rapid disposability of modernity and industrial capitalism in the late nineteenth century. While the exhibition buildings and displays lacked physical permanence, they continued to exist in the archive of official catalogs, newspapers, illustrated journals, books, lithographs, and photographs documenting the events and their discourses of progress. These written and visual records captured national displays and pavilions for historical posterity and for people unable to attend the fairs, including Brazilians who learned of their nation's representation abroad by reading O Novo Mundo. Exhibition displays contributed to the self-fashioning of a modern Brazil as elites translated an ideal vision of the nation based on its natural resources, economic potential, and creative ingenuity into a space visited by foreign delegates and a general public.

Beginning with the 1862 London fair, Brazil actively participated in these universal exhibitions by strategically displaying agricultural products, native cultures, and raw materials alongside the nation's “civilized” features. As Hardman astutely observes, Brazil crafted itself as modern in part through the comparative categorizing, cataloging, and displaying of natural resources and other products at nineteenth-century world's fairs (109). Showcasing Brazil's commodities facilitated its insertion into the "concert of modern nations" in an unequal manner compared to industrializing nations of Europe and North America, since its role in the global economy depended upon the extraction and exploitation of its raw materials. In this age of export and spectacle, universal exhibitions and scientific expeditions emerged as analogous activities of cataloging the world based on nations' natural resources and economic potential. The resulting hierarchy evidenced in the layout of the exhibition space reflected 
evolutionist views favored by Western modernity. As understood by Walter Mignolo, “'modernity' is a complex narrative whose point of origination was Europe; a narrative that builds Western civilization by celebrating its achievements while hiding at the same time its darker side, 'coloniality'” (2-3). This darker, constitutive element refers to beliefs, systems, and modes of thought often linked to historical colonialisms that have underpinned Western civilization since the Renaissance. As a spectacle of the industrial age, the Centennial Exhibition celebrated modernity and downplayed its darker side, even as former colonies like Brazil showcased natural resources susceptible to extractive, neocolonial relations. Schwarcz illustrates the logic of coloniality undergirding the exhibition's categorization, which situated Western nations at the peak of civilization and African and indigenous cultures as the "past" of humanity ("Os trópicos como espetáculo” 199). In spite of Dom Pedro’s desires to depict Brazil at these exhibitions as a modern nation rather than an exotic one, Schwarcz convincingly argues that, during the 1862 London Exhibition, "como sempre, para fora era o nosso lado exótico que estava em pauta e pouco se alterava a imagem do país” (205). The image of Brazil as an exotic nation of diverse flora, fauna, and natural resources persisted and would serve as the basis for representations of Brazil in subsequent exhibitions.

\section{Setting the Stage for 1876: O Novo Mundo on Earlier Exhibitions and Preparations}

O Novo Mundo reported extensively on world's fairs before and during the Centennial Exhibition in order to inform their readers of representations of Brazil abroad and new industrial technologies. The periodical first dedicated coverage to these fairs with a March 24, 1873 article on the Vienna Exhibition observing that Brazil suffered from a comparatively weak display. The collection in Vienna would be worse than previous displays in Paris due to "a estagnação do espírito público, e, podemos acrescentá-lo, uma indiferença nos cidadãos causada pela suposição que o Governo toma conta de tudo" $(3.30,103) .{ }^{6}$ This reliance on government planning and corresponding lack of involvement of private citizens

\footnotetext{
${ }^{6}$ I have updated the spelling in quotations from $O$ Novo Mundo to follow current orthographic conventions.
} 
and industry resulted in a Brazilian display that was, according to $O$ Novo Mundo, “tão minguada e tão injusta a natureza e a já nascente indústria do país” (3.30, 103). Speaking from a privileged position in New York with access to sources and current events in Brazil, Europe, and the United States, the periodical suggested that national elites could correct this underrepresentation of Brazilian resources and industry at the Vienna exhibition during the next world's fair in Philadelphia.

O Novo Mundo dedicated two more articles to the Vienna exhibition in the November 1873 issue. "O Pinho do Brasil" praised the excellence of the Brazilian pine and highlighted the industrial and commercial potential of these trees from Paraná. An accompanying image captured how the 33-meter tall araucaria braziliense, which had been divided into twenty pieces and reassembled, towered over nearby buildings. By stressing the quality of natural resources on display at the exhibition, O Novo Mundo affirmed that Brazil's development depended upon the role of its wood and other raw materials in a global, capitalist system $(4.38,33)$. Another article about the Vienna exhibition underscored the importance of Brazilian coffee, which further emphasized natural resources as key to Brazil's insertion into incipient industrial capitalism. The periodical recognized the role of universal exhibitions in crafting images of Brazil as modern for foreign audiences as it praised Brazil for receiving two diplomas of honor and 150 medals in Vienna $(4.38,31)$. By translating foreign views of Brazil grounded in its primary resources, O Novo Mundo acknowledged and reinforced the supposed paradox of Brazil as exotic and modern.

As preparations for the Centennial Exhibition in Philadelphia continued, the journal expressed an increased interest in the role of exhibitions in the construction and circulation of Brazil as modern. For the nations of the Americas, the 1876 exhibition represented a chance to showcase natural resources, manufactured goods, and industrial technologies. Rydell explains that the Centennial Exhibition "was intended to teach a lesson about progress. The lesson was far from benign, for the artifacts and people embodied in the "world's epitome" at the fair were presented in hierarchical fashion and in the context of America's material growth and development” (15). The layout revealed what Rydell considers the racist motivations behind the classification system, an observation not included in O Novo Mundo. Nationalist and imperialist projects accompanied the racist organizing principles of the exhibition, as architectural 
historian Bruno Giberti rightly contends (93). For the United States, the Philadelphia exhibition provided an opportunity to emerge as a global, industrial leader. Brazil similarly viewed the Centennial Exhibition as critical to its recognition as modern. The fact that the exhibition took place in the Americas for the first time increased the extent of Brazil's involvement (Hardmann 95). Brazil actively participated in the Philadelphia fair with elaborate displays and Dom Pedro's visit.

Dom Pedro II believed that Brazil could gain visibility as modern based on its role at the universal exhibitions, leading him to participate in commission preparations and opening day events. Brazil crafted itself as modern by showcasing natural resources next to developments in industry, science, and the arts. Although the emperor and elites wanted to present Brazil as more than simply exotic, they foregrounded the potential of its raw materials and commodities. Brazil had entries in all areas of the Centennial Exhibition: mining and metallurgy, manufacturing, education and science, art, machinery, agriculture, and horticulture. Yet, as Schwarcz astutely argues, the nation really only seemed to convince itself, and thus the rest of the world, of its primary resources (“Os trópicos como espetáculo” 208). The exhibition’s statistics confirm this claim as Brazil displayed a vast range of natural resources and only a token number of industrial, manufactured items. ${ }^{7}$ Reflecting on Brazil's presence at the world's fairs from 1862 to 1889, Schwarcz concludes that, for Brazilians, the nation's representation was both civilized and tropical, while, for foreigners, Brazil remained a country of tropical goods and resources (217). National elites believed that Brazil's natural resources would facilitate economic growth and lead to industrial development. Though informed by Western concepts of progress, the "civilized" side of Brazil relied on its autochthonous goods. Displays at world's fairs reinforced the image of Brazil as a tropical paradise, even as they attempted to showcase the nation as modern.

\footnotetext{
${ }^{7}$ See Giberti for more on the classification system. A scan of the catalog confirms that Brazil's most significant contribution was agricultural with eight pages listing its coffee, medicinal plants, and tobacco. Plant and animal products included land animals, sugar, and liquor. The nation had one page in the machinery section of the catalog. The fine arts section listed only 22 items, including portraits, landscapes, and historic scenes. Brazil had 79 items in mining and metallurgy, outpacing Mexico's 27. Argentina and Mexico both had a larger manufacturing presence than Brazil, whose manufactured goods included chemicals, ceramics, furniture, silk, yarns, medicine, and carriages. Brazil contributed 64 entries to the education and science division, compared to 372 items from the United States.
} 
Newspaper articles, illustrations, and other archival records translated representations of Brazil at universal exhibitions, which were in themselves translations of the nation for a foreign audience, back to a public in Brazil. As a journal closely observing the Philadelphia proceedings from its place of publication in New York, O Novo Mundo occupied a prominent position among narratives of Brazil at the Centennial Exhibition for a Brazilian readership. Its coverage of preparations for the Philadelphia exhibition began over a year and a half before it opened with a December 1874 article "A Exposição em Philadelphia.” In addition to informing Brazilian readers of the commission's work to procure funds, establish a budget, and plan the display, the article highlighted that Brazil would receive more space than any other Latin American nation $(5.51,71)$. Statistics of the layout allowed readers in Brazil to visualize the spatial arrangement of the exhibition and the prominence allocated to their nation. With reports emphasizing the ambitious nature of the endeavor and insisting on the commission's ability to complete it on time and budget, $O$ Novo Mundo followed the preparations for the Centennial Exhibition more closely than its Brazilian counterparts. ${ }^{8}$ The physical layout of the exhibition received a more detailed explanation in a March 1875 article about the main hall's features and other buildings' sizes and functions. The journal observed the fair's temporary nature by mentioning that only the gallery of fine arts, with its durable materials of granite, iron, and glass, would exist permanently.

To provide its Brazilian readers with a better sense of the exhibition, O Novo Mundo included illustrations of the plans for the main hall, agricultural hall, and fine arts gallery. The images highlighted the extravagance of buildings and their architectural styles, which echoed the elaborate arches, columns, and ornamentation of previous world's fairs. By emphasizing the financial, architectural, and industrial capacities of its northern neighbor, the periodical suggested to Brazilian readers the ongoing shift of economic power from Europe to the Americas. Illustrations in the journal demonstrated how exhibition buildings, which resembled European palaces, churches, and monuments, contrasted with the natural surroundings of the fair $(5.54,160-1)$. These images translated for Brazilian readers the supposed contradictions of the United States

${ }^{8} \mathrm{O}$ Novo Mundo began its coverage after the initial planning phases, so its optimistic reports did not include earlier struggles between the commission, architects, and engineers over designs, installation, and the fair's classification system. For more on these conflicts, see Giberti. 
and, by extension, other parts of the hemisphere containing both the exotic and the civilized. O Novo Mundo's coverage of the exhibition preparations continued in a September 23, 1875 article on the commission's final plan for space distribution in the main exhibition hall. Only the United States, France, Great Britain, Germany, Austria, Canada, and Australia would occupy more physical space than Brazil. Whereas other South American nations shared a space, Brazil received its own allotment near the center of the hall. By emphasizing Brazil's prominent position across from the United States, the periodical suggested a possible proximity between these two hemispheric giants in terms of economic potential and future progress.

In addition to the principle structures, the fairgrounds would include national pavilions and other minor buildings. In 1875, it remained possible to propose additional structures, so $O$ Novo Mundo expressed its desires for the Brazilian contribution by wondering: "[N]ão haverá no Brasil algum botequinista empreendedor que venha aqui fornecer café tal qual se bebe no Rio de Janeiro e que é uma perfeita revelação comparado com o que aqui se chama café? Não será este um meio excelente de anunciar aquele produto?” $(5.60,286)$. The periodical posited that proper preparation of Brazilian coffee would facilitate the entrance of this prized commodity into the global marketplace. Based on their familiarity with consumer products from living in New York, the editors of $O$ Novo Mundo recognized which Brazilian goods would warrant positive attention from the exhibition's public. They translated their experiences abroad into recommendations for Brazil's displays, which informed the images, materials, and goods representing Brazil in Philadelphia. As suggested by the periodical, the exhibition featured a Brazilian-style café. A September 1876 article accompanied by an image of the café explained to readers that the café served genuine Brazilian coffee since "a grande massa dos visitantes da Exposição não sabe discernir a qualidade dos diferentes grãos do precioso arbusto, mas pode apreciar o que seja uma xícara de bom café” $(6.72,261)$. The periodical anticipated that this enterprise would help make Brazilian coffee better known among consumers in the United States.

In the months leading up to opening day, O Novo Mundo dedicated more coverage to the Centennial Exhibition, which coincided with the centennial of U.S. independence. The periodical commemorated this anniversary with a January 1876 article recognizing the importance of liberty to democratic 
processes. The piece praised the model of government in the United States by claiming that "o seu regime é o mais apropriado à civilização porque é o mais natural ao homem. Os Estados Unidos têm democratizado o mundo inteiro" $(6.64,74)$. The article's hemispheric perspective credited the United States with spreading values of democracy and reiterated the periodical's goal of informing Brazilian readers of developments in the United States. Dom Pedro's visit to the United States would contribute to this learning process and exchange between the two nations. On his transcontinental travels, the emperor became a student of politics, economics, education, and culture in the United States. ${ }^{9}$ By applauding the governing practices of the United States and highlighting the role of Dom Pedro as a translator linking the two nations, O Novo Mundo positioned itself as a journal invested in hemispheric progress and thus interested in the geopolitical, economic, and cultural impacts of the Centennial Exhibition.

The periodical viewed the Centennial Exhibition, along with scientific travels, political relations, and commercial trade, as essential to the increased interactions between Brazil and the United States. In early 1876, an article noted that Brazilian coffee accounted for nearly four fifths of coffee in the United States due to its abundance, quality, and fair pricing $(6.64,81)$. By highlighting the prominence of coffee as a Brazilian export, the periodical reinforced the image of Brazil as a source of raw materials, which diminished recognition of its incipient industry. In January 1876, O Novo Mundo highlighted the centrality of industry to the Centennial Exhibition by describing it as "um grande acontecimento industrial do século," but questioned whether the Brazilian government would take heed of this industrial trend $(6.64,75)$. The journal recognized the government's desire to represent Brazil well, but lamented that "a coleção de objetos que ele vai mandar a Philadelphia [...] é muito incompleta" $(6.64,75)$. In particular, the Amazon would receive limited visibility in the Brazilian displays at the Centennial Exhibition. Since expeditions of Louis Agassiz, Charles Frederick Hartt, and other scientists had informed residents of the United States of the natural wealth of the Amazon, O Novo Mundo contended that Brazil's displays in Philadelphia should include resources from this region. Based on their familiarity with what a public in the United States would expect of a Brazilian display, the periodical's editors critiqued the commission for

\footnotetext{
${ }^{9}$ See Cribelli for more on the emperor's visit.
} 
overlooking materials from the Amazon. The periodical expressed a desire for Brazil to be seen as a modern site of industrial growth and a tropical repository of natural resources, revealing the paradox that Schwarcz identifies in nineteenthcentury Brazilian nationalist discourses.

Moving between New York and its readers in Brazil, the $O$ Novo Mundo occupied a privileged position as a translator with access to information in both nations that allowed it to create a more complete view of Brazil's presence in Philadelphia. The periodical criticized Brazil for delays in its exhibition planning given that, three months before opening day, the government had yet to name commission members. The journal received complaints from exhibition planners in Philadelphia about the poor organization of Brazil, but could counter those negative accounts by consulting reports in Brazilian newspapers on the exhibition, such as an article in A Nação explaining that the Brazilian commission would consist of eight members. O Novo Mundo cynically suggested that the delays and lack of planning resulted from the government remaining faithful to its maxim, "Não fazer hoje o que pode ser feito amanhã” (6.65, 95). Though it criticized policies of the Brazilian government at times, the periodical defended Brazil and advocated for its favorable representation at the exhibition. The journal portrayed the Centennial Exhibition as a critical event for the representation of Brazil abroad. With articles and images detailing the exhibition's general layout, national displays, and technological innovations, $O$ Novo Mundo translated for its Brazilian readership the experiences of the Centennial Exhibition. The minutiae in these articles, such as the square footage allocated to Brazil in each section of the fair, helped readers to visualize the exhibition, especially the prominent place that Brazil would occupy, without traveling to Philadelphia. Accompanying illustrations further contributed to readers' conceptions of these displays. In its accounts of Brazil's preparations for the Centennial Exhibition, O Novo Mundo not only informed Brazilian readers of perceptions of Brazil in the United States, but also argued for the Brazilian commission to approach the national displays with seriousness and care.

\section{Dom Pedro's Travels and Brazil's Translations in Philadelphia}

Dom Pedro II's visit to the United States in 1876 and his decision to inaugurate the Centennial Exhibition next to President Grant indicate the value that he 
placed on Brazil's modern and civilized presence at the fair. For O Novo Mundo, the Brazilian emperor's transcontinental travels revealed hemispheric interests similar to the outlook proposed by the journal. A March 1876 article outlined the emperor's itinerary, which featured the diverse lands, peoples, and democratic institutions of the United States and the spectacle of the Philadelphia exhibition. The article suggested that Dom Pedro, as the first monarch to visit the United States, would bring prestige to the festivities in Philadelphia. As "obreiros humildes do desenvolvimento intelectual de nossa pátria," the editors of $O$ Novo Mundo encouraged Dom Pedro to observe life in the United States carefully, especially its democratic practices, educational opportunities, religious freedoms, and industrial developments, with an interest in potential models for the Brazilian context $(6.65,118)$. Living in and writing from New York allowed Rodrigues and his collaborators to observe governmental policies, social practices, and technological innovations in the United States first-hand and to share these experiences and information with readers in Brazil. As Brazilians in the United States, they contributed to the intellectual growth of Brazil by defending the nation, critiquing it at times, and advocating for translations of political, economic, educational, and social models from the United States to Brazil, which would involve creative transformations.

O Novo Mundo documented Dom Pedro's visit to the United States, which began with a welcoming reception from the Brazilian community in New York before departing for California two days later. The periodical, which "tem sempre procurado dizer a verdade” especially about the United States, hoped these travels would serve a pedagogical purpose by revising potential misconceptions held by the emperor and other Brazilians about their northern neighbor (6.66, 142). Traveling to San Francisco, St. Louis, New Orleans, and the Northeast would give the Brazilian leader a better sense of the United States. Although the article lamented the fast pace of his transcontinental journey, it contended that it would be impossible for Dom Pedro to overlook "as feições mais salientes do estupendo progresso desse povo” $(6.66,142)$. Subscribing to a Western vision of progress, the periodical considered industrial manufacturing, technological innovations, educational opportunities, and other political, economic, social, and cultural developments in the United States as examples of desirable, forward movement. After outlining the sights that the emperor would see on his travels, the article claimed that "todo este espetáculo, e afinal, o da síntese do progresso 
americano na Exposição de Philadelphia vai de certo causar profunda impressão no ânimo imperial. [...] Oxalá que toda esta lição não seja perdida e que por amor da nossa pátria comum [...] ele anime realmente o espírito de iniciativa, a autonomia individual, base da grandeza de todo e qualquer país” $(6.66,142)$. The periodical framed Pedro II as a traveler observing models of progress in the United States that he would later translate to the Brazilian context. O Novo Mundo covered the emperor's travels with the needs of the Brazilian nation and reading public in mind. Their articles lacked the exhaustive details and excessive enthusiasm evident in the New York Herald's documentation of Dom Pedro's transcontinental travels. ${ }^{10}$ Instead, guided by an interest in the future of Brazil, the periodical focused on developments that Dom Pedro would encounter in the United States and that could impact policies and practices he would later promote in Brazil.

Since $O$ Novo Mundo viewed the Centennial Exhibition as an opportunity for Brazil to display itself on a global stage, the periodical devoted more attention to the proceedings in Philadelphia with its inauguration. The May 27, 1876 issue featured on its cover an illustration of the Brazilian pavilion and an article titled "A lição de um século," which pondered the history of great nations and whether differences in race or political institutions would matter more in the future. These anecdotal reflections allowed the newspaper to speculate about Brazil's position among the representation of modern nations at the exhibition. Through the journal's description of buildings, displays, and pavilions, its Brazilian readers got the sense that the Centennial Exhibition served "como uma bela representação do estado atual das indústrias e artes” $(6.68,166)$. The journal informed readers that this feat was even more impressive since the exhibition's funding came exclusively from the private sector. The May issue included a map of the grounds and articles describing opening day events, outlining the displays, and guiding readers on a tour of the main hall, which helped them visualize the experience of visiting the fair without leaving Brazil. The periodical's narration of the main hall highlighted the United States' elaborate displays of

\footnotetext{
${ }^{10}$ The New York Herald contained special reports, likely written by James Kelly, documenting Dom Pedro's journey from Rio de Janeiro to New York and across the United States. As the first monarch to visit the U.S., Dom Pedro received the press coverage reserved for celebrities with articles describing him as the "American emperor" and commenting that they were "proud to note in him the go-ahead American traits” (“Dom Pedro in U.S.”).
} 
manufactured goods, including clothes, instruments, and furniture, as well as the prominence of Brazil in the main hall, near France, Belgium, and the Netherlands. Articles and images captured the spectacle of the exhibition, which emphasized "civilized" culture and industrial progress of Western modernity.

In translating exhibition displays for a Brazilian readership, O Novo Mundo echoed official catalog entries at times and asserted editorial opinions grounded in an interest in progress. For instance, the journal claimed that "de todas as colônias [inglesas] aí representadas o mais importante para nós é o Canadá. [...] O visitante do Sul fica surpreendido com o progresso do Canadá” $(6.68,167)$. With its manufactured goods like sewing machines and chemical products, Canada impressed Novo Mundo, and it emerged as an example of how Brazilian industry could develop. As it described European displays, the periodical expressed a commitment to Brazilian interests by stressing the nation's superior natural resources. The section on the Dutch presence at the fair presented a comparison of their prized coffee commodities, stating that, "O que é muito inferior ao nosso [...] é o café de Java” (6.68, 169). By emphasizing the superiority of Brazilian coffee to their readers, the periodical, with its nationalist sentiment, positioned this resource as critical to Brazil's emerging commercial identity within a global capitalist system.

O Novo Mundo further developed its depiction of Brazil at the Centennial Exhibition with a detailed, two-page article highlighting the country's displays in the main, agricultural, fine arts, and machinery halls. To create a more vivid image of the pavilion, the article referred to New York Tribune's comparison of the structure to Arabic palaces, stressing its material details and colors to add vibrancy to the accompanying black-and-white illustration (see fig. 1):

O pavilhão brasileiro faz a gente lembrar-se dos palácios imaginários de ouro e pedras preciosas dos génios das Noites arábicas. Consiste de colunas e pilares de madeira, suportando capitéis ricamente ornamentados; e de arcos, sobrepostos aos quais está uma superestrutura também pintada com cores muito vivas. A fachada e as portas interiores são ornadas de azulejos de vidro transparente, atrás dos quais há desenhos de lindas cores. [...] As cores empregadas nos ornatos são o verde e o amarelo, o azul e o encarnado. $(6.68,170)$ 
Designed by Philadelphia architect Frank Furness, the Brazilian pavilion stood out with its excessive ornamentation blending Moorish and Victorian styles (Giberti 111).

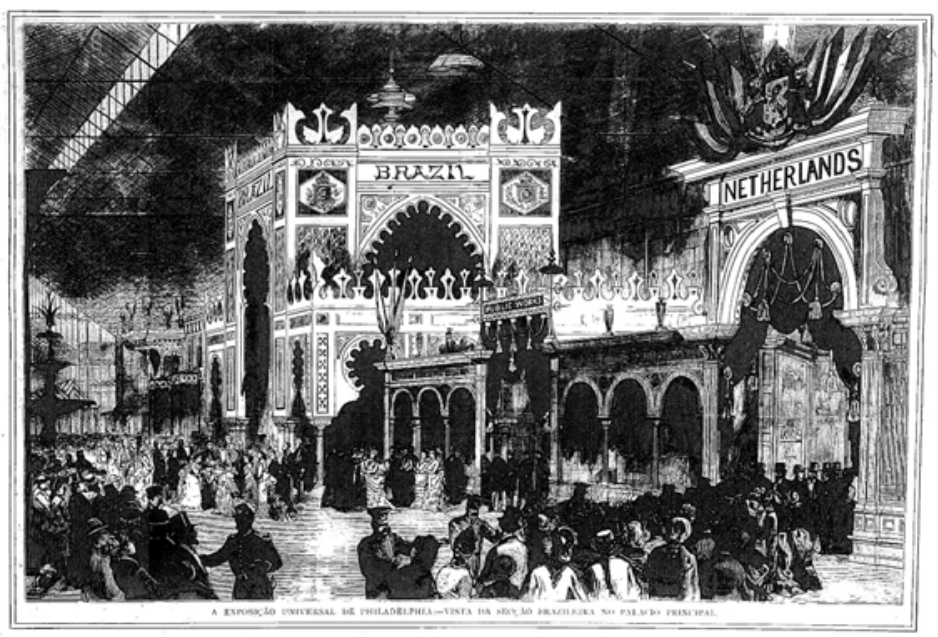

Fig. 1. Illustration of Brazil’s Main Building in O Novo Mundo, 6.68, Supplement

It distinguished itself from European displays with its towering height, glass tiles, and decorative painting in green, yellow, blue, and scarlet, the colors of the imperial flag representing tones of the Brazilian land. The architecture, in contrast, was not inspired by Portuguese styles or autochthonous traditions. The structure used elaborate columns and arches in an orientalist gesture that marked Brazil as exotic in an aesthetic form already familiar to exhibition visitors. ${ }^{11}$ The Brazilian display received significant public attention and awards for its design. For instance, in Edward C. Burke's 1877 unofficial account of the fair, he praises Brazil's structure in a comparative manner: "The Moorish colonnade of the Brazilian pavilion lifts its head in graceful rivalry of the lofty front reared by the other branch of the Iberian race” (98). While Brazil was the only Latin American

\footnotetext{
${ }^{11}$ See Said for more on how Western culture employs orientalist practices and aesthetics. Latin American scholars note the use of orientalist discourses to conceive of and represent the unknown, as Altamirano observes with Sarmiento's analogy between the pampas and the deserts of Arabia. This description rendered the pampas both exotic and familiar, a gesture similar to the pavilion's architecture.
} 
country to erect its own building on fairgrounds, Spanish American nations accounted for eleven of the thirty-seven countries that participated in the exhibition. By displaying Inca relics, silver, and other natural resources, Spanish American nations similarly curated an exotic otherness of goods prone to exploitation. ${ }^{12}$ Brazil, however, strove to transcend its exotic identity by attracting the attention of visitors with the size, colors, and ornamentation of its structures. The official catalog entry of Brazil and its presence throughout the exhibition similarly exuded an interest in its visibility among modern nationstates.

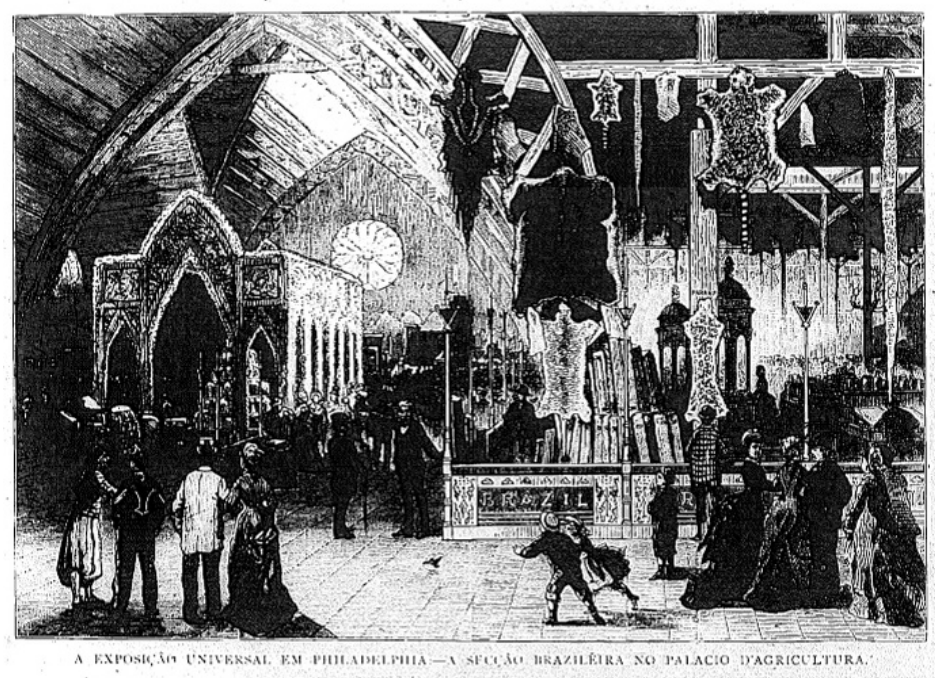

Fig. 2. Brazilian Section in Agricultural Hall in O Novo Mundo (6.69, 200)

Articles and images in O Novo Mundo depicted how Brazil represented itself as both modern and exotic and how those images were received by foreign audiences at the Centennial Exhibition. After concentrating on Brazil's "civilized" side in the May 1876 edition with written and visual accounts of the nation's prominence in Philadelphia as illustrated, the periodical focused in its

\footnotetext{
${ }^{12}$ Besides Brazil, ten other nations, including Spain and Portugal, built structures at the Centennial Exhibition. Argentina, Bolivia, Chile, Colombia, Ecuador, Guatemala, Honduras, Mexico, Nicaragua, Peru, and Venezuela, as the Spanish American participants, were allocated to shared sections of the main exhibition hall. See Andermann for a comparative reading of Brazil and Argentina at universal and national exhibitions in the late nineteenth century. See Tenorio for more on the curating of Mexico as modern at the world's fairs, especially the 1889 Paris Exposition.
} 
next issue on the agricultural products and natural resources showcased in the nation's displays. By informing its readers of the economic value of Brazilian coffee and rubber, the journal underscored the centrality of these commodities to the project of a modern Brazil. A black-and-white image of Brazil's agricultural display captured the contrast between its exotic products and the refinement of exhibition visitors (6.69, 200, see fig. 2). This illustration rendered a house-like cotton structure at the image's shadowy edge as plain and dark, especially in comparison to the distinctive texture and relative whiteness of the cotton building in photographs of agricultural hall. The image focused on the stretched-out animal carcasses hanging from the ceiling rungs, underscoring the "savage" elements of Brazil. With this visual juxtaposition, the periodical suggested, without explicitly critiquing, that Brazil, even as it embraced Western modernity, could not escape the logic of coloniality that reduced the former Portuguese colony to its primary resources susceptible to extraction. Striving to portray Brazil as civilized, the exhibition organizers did not recognize the negative consequences of defining the nation solely in terms of natural resources. O Novo Mundo espoused a belief in progress as it translated contrasting images of Brazil as civilized and exotic. As the periodical implied, but did not expressly criticize, Brazil's emergence as modern in the system of global, industrializing capitalism depended upon the extraction and consumption of its raw materials.

While not among the ten million who visited the Philadelphia site, an elite public in Brazil could figuratively travel to the Centennial Exhibition by reading reports in the pages of $O$ Novo Mundo. These readers got a better sense of the exhibition's six-month run via lithographic prints and brief articles in the August issue about the sights and experiences in Philadelphia. The periodical highlighted Brazil's emerging manufacturing abilities with illustrated, step-by-step instructions that outlined how to grow silk worms, process the fibers, and produce silk $(6.71,237)$. This piece created a more complete image of Brazil's presence at the fair by underscoring artisanship and technical skills, rather than solely emphasizing its natural resources. Another article cited Brazil's 350 medals as evidence of the nation's success at the exhibition $(6.71,234) .{ }^{13}$ This piece also explained how Brazil aimed to further extend knowledge of the nation

\footnotetext{
${ }^{13}$ A complete listing of these awards and the honored Brazilians appeared in the subsequent issue (6.72, 258-259).
} 
across the United States by distributing O Brasil na Exposição de Philadelphia to universities and libraries. Unlike the temporary structures of the exhibition, this book granted greater permanence to the event by recording Brazil's claims to modernity in words and images. Beatriz González Stephan argues that such written records "testified to these facts for the benefit of all those who had not been present at the expositions themselves. These catalogs became, in effect, a genre in themselves, as inventories of the merchandise on display, while quantifying, enumerating, imposing uniformity, and fitting Latin American products and ideas into a preexisting rhetoric” (231). The written catalog of Brazil at the Philadelphia Exhibition inscribed the nation's featured natural resources, manufactured goods, and cultural works into the classificatory logic of Western modernity. By mentioning this book, O Novo Mundo informed Brazilian readers of an ongoing concern with educating residents of the United States about Brazil. Representing Brazil as modern at the exhibition with an accompanying catalog facilitated its emergence on a global stage, yet had the sinister effect of aiding extractive economies as evidenced by the rubber boom.

In its January 1877 issue, $O$ Novo Mundo reflected on the Brazilian experience during the Centennial Exhibition, which closed on November 10, 1876. The journal recognized that more visitors had attended the Philadelphia event than any previous universal exhibition, but lamented that few foreigners, besides the national commissions, visited the fair $(7.73,4)$. The exhibition was a popular event attended by one-fifth of all residents in the United States (Rydell 49). The fair allowed these visitors to experience other nations by absorbing the images and information of displays and pavilions, instead of embarking on expensive travel abroad. By pairing an article about attendance at the exhibition with images of Brazil's displays, O Novo Mundo reminded its readers that the Philadelphia fair facilitated the "travel" of foreigners, especially residents of the United States, to Brazil by showcasing the nation's resources, culture, and economic potential. Their reporting depicted how visitors wandering through the main hall and auxiliary structures could learn about Brazil's natural resources and commodities, observe its developing machinery and manufactured goods, taste Brazilian coffee, and enjoy its artistic expressions.

The periodical noted that Brazilian paintings in the fine arts hall conveyed nationalistic sentiments with representations of valiant Brazilian soldiers in the Paraguayan War (1864-1870) or bucolic foundational scenes, most notably 
Victor Meirelles’s Primeira missa no Brasil (1860). This painting depicts what art historian Jorge Coli terms “o ato de batismo da nação brasileira” (110). A cross and priest occupy the focal point of the painting from which light emanates out to other Portuguese priests and explorers in order to portray Catholicism and European colonialism as civilizing forces in Brazil. Mostly naked indigenous bodies exist in the shadows at the front and side of the painting, contrasting the idealized images in the background of coastal Brazil with palm trees and lush green foliage. With this iconic Romantic representation of the baptism of Brazilian land and people as colonial entities, Brazil's artistic display echoed the Centennial Exhibition's celebration of progress by idealizing Western modernity while relegating its dark underside of coloniality to the margins and rendering it invisible. While $O$ Novo Mundo did not critique the ideology encoded in the image nor provide a detailed description or reproduction of the painting, the periodical mentioned the positive reception of Meirelles's work in Englishlanguage sources, including the accounts of Frank Leslie and Edmund Burke. The response to these paintings indicated that the Brazilian commission had successfully showcased the nation's cultural promise to exhibition visitors, even if the artistic works recreated the intertwined logic of modernity and coloniality. The periodical concluded its coverage of the Centennial Exhibition by capturing the fair's contradictory, yet coexisting, representations of Brazil as modern and exotic for its Brazilian readership.

\section{Conclusion}

To translate representations of Brazil abroad to a readership at home, O Novo Mundo dedicated articles and illustrations to Dom Pedro's transcontinental travels and the Brazilian displays at the 1876 Centennial Exhibition. At this first world's fair held in the Americas, the United States and Brazil exhibited their disparate claims to Western modernity alongside other nations through unequal displays of natural resources, technological developments, and creative expressions. By reading accounts of the fair in O Novo Mundo alongside archival documentation and histories of the Centennial Exhibition, I situate the periodical as a translator bridging the hemispheric distance between the United States and Brazil. With its access to sources, people, and experiences in both nations, the journal provided a more complete view of Brazil's presence in Philadelphia and 
the reception of its curated image as a modern and exotic nation. Through its articles and editorial perspective, $O$ Novo Mundo recognized and reinforced this elite desire for Brazil to become modern. At times, the journal critiqued official plans and preparations for the representation of Brazil at the universal exhibitions, or raised questions about how certain models of progress would transfer to Brazil. In spite of these critiques, the periodical and its editors embraced a hemispheric vision of progress that blinded them to the darker side of modernitycoloniality - which would leave Brazil and its natural resources susceptible to exploitative relationships of extraction.

\section{Works Cited}

Agassiz, Louis, and Elizabeth Cabot Agassiz. A Journey in Brazil. Tinker and Fields, 1868.

Altamirano, Carlos. "El orientalismo y la idea del despotismo en el Facundo." Ensayos argentinos: de Sarmiento a la vanguardia, edited by Carlos Altamirano and Beatriz Sarlo, Ariel, 1997, pp. 83-102.

Andermann, Jens. "Tournaments of Value: Argentina and Brazil in the Age of Exhibitions.” Journal of Material Culture, vol. 14, no. 3, 2009, pp. 333-63.

Barman, Roderick J. Citizen Emperor: Pedro II and the Making of Brazil, 182591. Stanford UP, 1999.

Beckman, Ericka. Capital Fictions: The Literature of Latin America's Export Age. U of Minnesota P, 2012.

Boehrer, George C.A. "José Carlos Rodrigues and O Novo Mundo, 1870-1879.” Journal of Inter-American Studies, vol. 9, no. 1, Jan. 1967, pp. 127-44.

Burke, Edward C. The Century: Its Fruits and its Festival. Lippincott, 1877.

Brasil, Comissão à Exposição Universal. O Império do Brazil na Exposição Universal de 1876 em Philadelphia. Typographia Nacional, 1875.

Brasil, Museu Imperial. Setor de Documentação e Referencia. D. Pedro II na Exposição de Filadélfia em 1876/IBPC. Museu Imperial, 1993.

Campos, Gabriela Vieira de. "O literário e o não-literário nos textos e imagens do periódico ilustrado O Novo Mundo (Nova Iorque, 1870-1879).” MA thesis, U Estadual de Campinas, 2001. 
Coli, Jorge. "Primeira Missa e Invenção da Descoberta.” A descoberta do homem e do mundo, edited by Adauto Noves, Companhia das Letras, 1998, pp. 10721.

Costa, Emília Viotti da. The Brazilian Empire: Myths and Histories. Revised edition, U of North Carolina P, 2000.

Cribelli, Teresa. "A Modern Monarch: Dom Pedro II's Visit to the United States in 1876.” The Journal of the Historical Society, vol. 9, no. 2, June 2009, pp. 223-54.

“Dom Pedro II in the U.S.” New York Herald, 16 Apr. 1876.

Giberti, Bruno. Designing the Centennial: A History of the 1876 International Exhibition in Philadelphia. UP of Kentucky, 2002.

González Stephan, Beatriz. "Showcases of Consumption: Historical Panoramas and Universal Expositions.” Beyond Imagined Communities: Reading and Writing the Nation in Nineteenth-Century Latin America, edited by Sara Castro-Klarén and John Charles Chasteen, Woodrow Wilson Center, 2003, pp. 225-38.

Hardman, Francisco Foot. Trem-fantasma: a ferrovia Madeira-Mamoré e a modernidade na selva. 2nd ed., Companhia das Letras, 2005.

Hartt, Charles Frederick. Geology and Physical Geography of Brazil. Fields, Osgood, \& Co., 1870.

Mignolo, Walter D. The Darker Side of Western Modernity: Global Futures, Decolonial Options. Duke UP, 2011.

Norton, Frank H., and Frank Leslie. Frank Leslie's Historical Register of the United States Centennial Exposition, 1876. Paddington, 1974.

Plum, Werner. World Exhibitions in the Nineteenth Century, Pageants of Social and Cultural Change. Friedrich-Ebert-Stiftung, 1977.

Rinaldi Asciutti, Mônica Maria. "Um lugar para o periódico O Novo Mundo (Nova Iorque, 1870-1879).” Dissertation, U de São Paulo, 2010.

Rodrigues, José Carlos, editor. O Novo Mundo: Periódico Ilustrado do Progresso da Edade. 1870-1879.

Rydell, Robert W. All the World's a Fair: Visions of Empire at American International Expositions, 1876-1916. U of Chicago P, 1984.

Said, Edward. Orientalism. Pantheon, 1978.

Schwarcz, Lilia Moritz. O espectáculo das raças: cientistas, instituições e questão racial no Brasil 1870-1930. Companhia das Letras, 1993. 
-. The Emperor's Beard: Dom Pedro and the Tropical Monarchy of Brazil. Translated by John Gledson, Hill and Wang, 2004.

—. "Os trópicos como espetáculo: a participação brasileira nas exposições universais de finais do século XIX.” Galerías del progreso: museos, exposiciones y cultura visual en América Latina, edited by Beatriz González Stephan and Jens Andermann, Beatriz Viterbo, 2006, pp. 195-220.

Seigel, Micol. Uneven Encounters: Making Race and Nation in Brazil and the United States. Duke UP, 2009.

Tenorio-Trillo, Mauricio. Mexico at the World's Fairs: Crafting a Modern Nation. U of California P, 1996.

Turazzi, Maria Inez. Poses e trejeitos: A fotografia e as exposições na era do espetáculo (1839-1889). Funarte, 1995. 